\title{
Studies on the Chemical Modification of Monensin. I. Synthesis and Crystal Structures of $\mathrm{NaBr}$ Complexes of Monensylamino Acids
}

\author{
Jinsaku Sakakibara,,${ }^{* a}$ Akito Nakamura,,${ }^{a}$ Shin-ICHi Nagai, ${ }^{a}$ \\ TAISEI UEDA, ${ }^{a}$ and TOSHIMASA ISHIDA ${ }^{b}$ \\ Faculty of Pharmaceutical Sciences, Nagoya City University, ${ }^{a}$ Tanabe-dori, \\ Mizuho-ku, Nagoya 467, Japan and Osaka University of Pharmaceutical \\ Sciences, ${ }^{b}$ 2-10-65 Kawai, Matsubara, Osaka 580, Japan
}

(Received May 30, 1988)

\begin{abstract}
Condensation of the polyether antibiotic monensin (1) with amino acid benzyl esters followed by debenzylation gave monensylamino acids $(3 \mathbf{a}-\mathbf{g})$, which were subsequently converted to the corresponding $\mathrm{NaBr}$ complexes $(\mathbf{4 a}-\mathbf{g})$. An X-ray crystallographic study on $4 \mathbf{e}$ clarified that the conformation of $\mathbf{4 e}$ differs from that of the $\mathrm{NaBr}$ complex of monensin (5) in that an intramolecular hydrogen bond is present between $O(3)$ oxygen and $O(11)$ hydroxy proton. This finding is consistent with the carbon-13 nuclear magnetic resonance signals of the methoxy carbons of $4 \mathbf{a}-\mathbf{g}$ which appear downfield relative to those of $3 \mathbf{a}-\mathbf{g}$. Compounds $3 \mathbf{a}-\mathbf{g}$ showed no anticoccidial activity.
\end{abstract}

Keywords — - monensin; chemical modification; monensylamino acid; sodium bromide complex; X-ray analysis; pseudocyclic conformation; hydrogen bond; ${ }^{13} \mathrm{C}-\mathrm{NMR}$; anticoccidial activity

The polyether antibiotic monensin (1, Fig. 1), an important agent in the control of coccidiosis in poultry, is one of a large class of naturally occurring ionophores which have attracted increasing attention because of their unusual chemical and biochemical properties.

In recent years, a number of investigations on the molecular structures, ${ }^{1}$ biological activities, ${ }^{2)}$ and chemical properties ${ }^{2,3)}$ of 1 have been reported, but the chemical modification of monensin structure and evaluation of the crystal structures of derivatives have not been well investigated, except for monensin C-26 urethane derivatives. ${ }^{4)}$ Monensin (1) has three reactive functional groups in the molecule: a carboxyl group at the $\mathrm{C}-1$ position and two hydroxy groups at the $\mathrm{C}-7$ and $\mathrm{C}-26$ positions. The two hydroxy groups are very important for the metal complex formation as shown in Fig. 2, and thus we have been interested in the chemical modification of the carboxyl group by condensation with optically active amino acids. In this paper we wish to report the preparation of monensylamino acids $(3 \mathbf{a}-\mathbf{g})$ and an $\mathrm{X}$-ray crystallographic analysis of the corresponding $\mathrm{NaBr}$ complex (4e) as well as the result of an examination of the anticoccidial activities of these compounds.

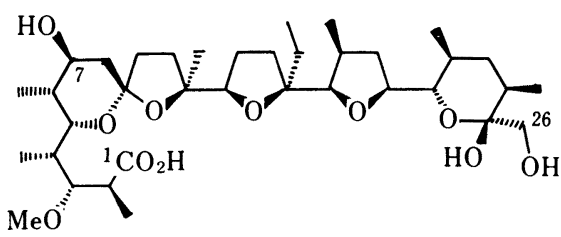

Fig. 1. Chemical Structure of Monensin (1)

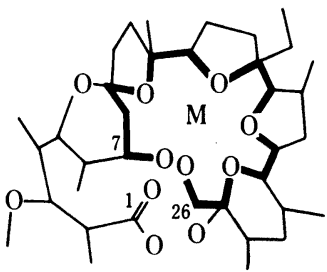

Fig. 2. Metal Complex of Monensin (1) 


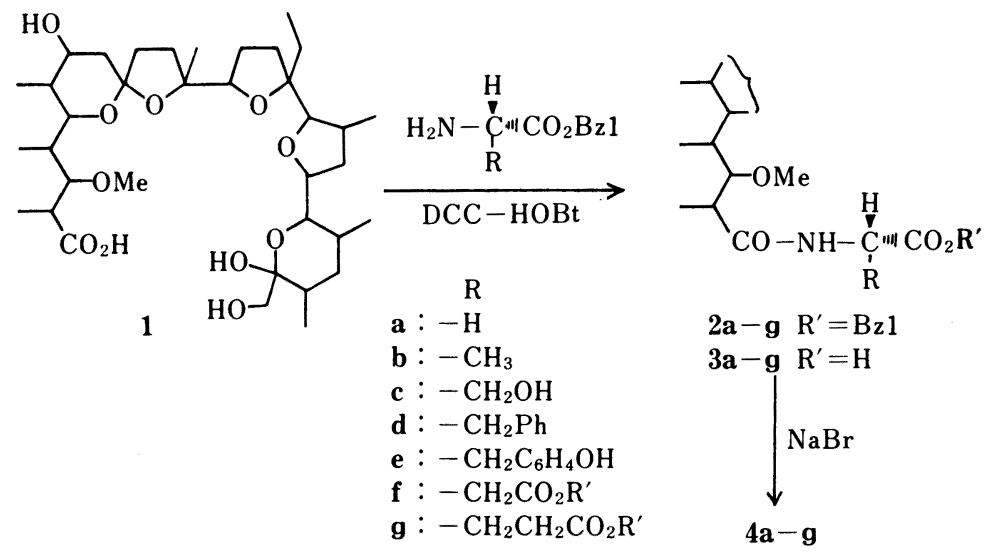

Chart 1
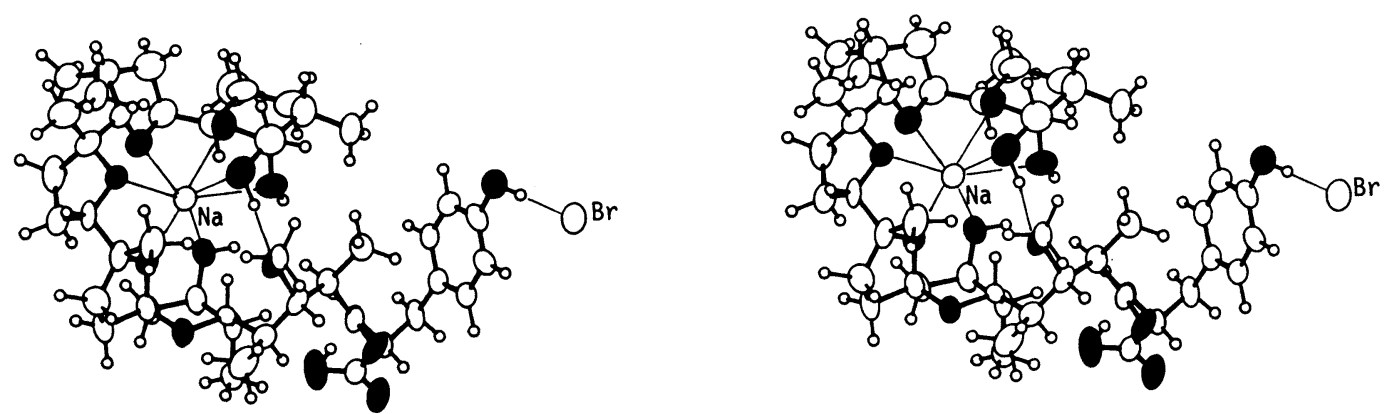

Fig. 3. Stereoscopic Drawing of $\mathbf{4 e}$ Oxygen atoms are shaded. Hydrogen and coordination bonds are indicated as lines.

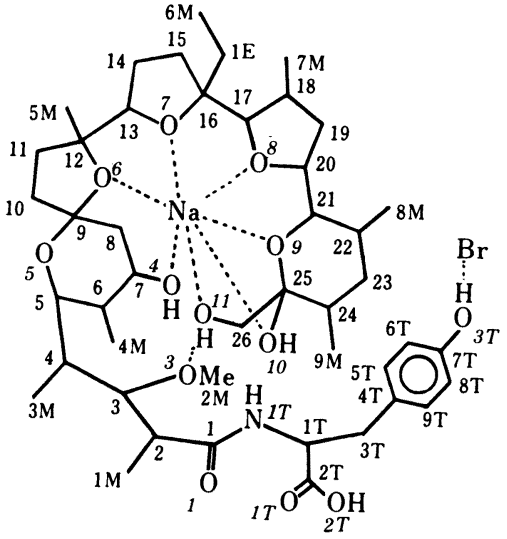

Fig. 4. Numbering of the Atoms in the Molecule of $4 \mathbf{e}$

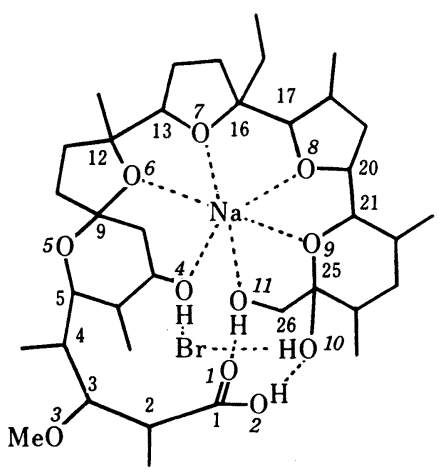

Fig. 5. Crystal Structure and Numbering of the Atoms in the Sodium Bromide Complex of Monensin (5)

\section{Chemistry}

Monensin (1), obtained by the reported ${ }^{5}$ method from commercially available sodium monensin, was condensed with amino acid benzyl esters in the presence of dicyclohexylcarbodiimide (DCC) and 1-hydroxybenzotriazole ( $\mathrm{HOBt}$ ) to provide monensylamino acid benzyl 
Table I. Atomic Parameters

\begin{tabular}{|c|c|c|c|c|}
\hline Atom & $x$ & $y$ & $z$ & $B_{\text {iso }}{ }^{a)}$ \\
\hline $\mathrm{Br}$ & $1.4681(1)$ & $0.2235(1)$ & 0.11479 (4) & $4.82(5)$ \\
\hline $\mathrm{Na}$ & 0.4007 (5) & $-0.1796(4)$ & $0.1391 \quad$ (1) & $4.0 \quad(2)$ \\
\hline $\mathrm{O}(1)$ & $0.8648(9)$ & $0.0684(7)$ & 0.0324 & $4.9 \quad(4)$ \\
\hline $\mathrm{O}(3)$ & $0.7541(8)$ & -0.2039 (6) & $0.0914 \quad(2)$ & 4.1 (4) \\
\hline $\mathrm{O}(4)$ & $0.3278(8)$ & $-0.0365(7)$ & 0.1028 & $4.2 \quad$ (4) \\
\hline$O(5)$ & $0.4340(8)$ & $-0.2421(6)$ & $0.0471 \quad(2)$ & $4.2 \quad$ (4) \\
\hline $\mathrm{O}(6)$ & $0.3502(8)$ & $-0.2864(6)$ & $0.0955 \quad(2)$ & 3.6 (3) \\
\hline $\mathrm{O}(7)$ & $0.3344(7)$ & $-0.3791(7)$ & 0.1537 & $4.0 \quad$ (4) \\
\hline$O(8)$ & 0.2299 (9) & $-0.1809(8)$ & 0.1796 & $5.0 \quad(4)$ \\
\hline$O(9)$ & $0.4687(9)$ & -0.0859 (7) & 0.1894 (2) & $4.6 \quad$ (4) \\
\hline $\mathrm{O}(10)$ & 0.5671 (9) & $-0.0048(8)$ & $0.1466 \quad(2)$ & $5.0 \quad$ (4) \\
\hline $\mathrm{O}(11)$ & 0.6481 (9) & -0.2151 (9) & $0.1537 \quad(2)$ & $5.8 \quad(5)$ \\
\hline $\mathrm{O}(1 \mathrm{~T})$ & $0.5885(9)$ & $0.3828(8)$ & 0.0003 & $5.7 \quad(5)$ \\
\hline $\mathrm{O}(2 \mathrm{~T})$ & 0.487 (1) & $0.2355(9)$ & 0.0194 & 8.2 (6) \\
\hline $\mathrm{O}(3 \mathrm{~T})$ & $1.1646(8)$ & $0.2567(8)$ & 0.1419 & 5.1 (4) \\
\hline $\mathrm{N}(1 \mathrm{~T})$ & $0.7029(8)$ & $0.1699(8)$ & 0.0545 & $3.2 \quad$ (4) \\
\hline$C(1)$ & 0.785 (1) & $0.0784(9)$ & 0.0523 & 3.2 (5) \\
\hline$C(2)$ & $0.766 \quad$ (1) & $-0.0066(9)$ & 0.0783 & 3.4 (5) \\
\hline$C(3)$ & 0.765 (1) & $-0.1290(9)$ & 0.0649 & $3.4 \quad(5)$ \\
\hline C(4) & 0.654 (1) & $-0.1492(9)$ & 0.0423 & 3.7 (5) \\
\hline$C(5)$ & 0.511 (1) & -0.1451 (8) & 0.0575 & $2.7 \quad$ (4) \\
\hline$C(6)$ & $0.430 \quad(1)$ & $-0.0380(9)$ & 0.0506 & $3.8 \quad(5)$ \\
\hline$C(7)$ & $0.300 \quad$ (1) & -0.046 & 0.0704 & $3.9 \quad(5)$ \\
\hline $\mathrm{C}(8)$ & 0.224 (1) & -0.155 & 0.0642 & 4.6 (6) \\
\hline$C(9)$ & 0.314 (1) & -0.2590 & 0.0647 & $4.0 \quad(5)$ \\
\hline$C(10)$ & 0.249 (1) & -0.367 & 0.0522 & $5.2 \quad(7)$ \\
\hline C(11) & 0.324 (2) & -0.463 & 0.0695 & 5.4 (7) \\
\hline$C(12)$ & $0.367 \quad(1)$ & -0.410 & 0.0998 & 4.4 (6) \\
\hline$C(13)$ & $0.284 \quad(1)$ & $-0.4405(9)$ & 0.1280 & $4.0 \quad(5)$ \\
\hline$C(14)$ & 0.135 (1) & -0.414 (1) & 0.1264 & $4.9 \quad(7)$ \\
\hline$C(15)$ & $0.098 \quad(1)$ & -0.387 & 0.1590 & 6.2 (8) \\
\hline$C(16)$ & 0.234 (1) & -0.384 (1) & 0.1781 & $5.0 \quad(7)$ \\
\hline$C(17)$ & 0.264 (1) & -0.281 & 0.1977 & $4.7 \quad(6)$ \\
\hline$C(18)$ & 0.192 (2) & -0.260 & 0.2279 & 8. (1) \\
\hline$C(19)$ & $0.242 \quad(2)$ & -0.138 & 0.2331 & $6.7 \quad$ (9) \\
\hline $\mathrm{C}(20)$ & 0.235 (1) & -0.086 & 0.2009 & 5.4 (7) \\
\hline $\mathrm{C}(21)$ & 0.354 (1) & -0.011 & 0.1922 & 5.0 \\
\hline$C(22)$ & $0.385 \quad(2)$ & 0.083 (1) & 0.2158 & 6.2 (8) \\
\hline$C(23)$ & $0.512 \quad(2)$ & 0.144 (1) & 0.2053 & 6.7 (9) \\
\hline$C(24)$ & $0.634 \quad(2)$ & 0.065 (1) & 0.1981 & 6.4 (8) \\
\hline$C(25)$ & $0.588 \quad(1)$ & $-0.033(1)$ & 0.1769 & 4.4 (6) \\
\hline $\mathrm{C}(26)$ & $0.687 \quad(2)$ & -0.133 (1) & 0.1761 & 6.6 (9) \\
\hline$C(1 E)$ & 0.997 (1) & -0.492 & $0.1970 \quad$ (4) & $7.3 \quad(9)$ \\
\hline $\mathrm{C}(1 \mathrm{M})$ & 0.882 (1) & $0.011 \quad$ (1) & $0.1010 \quad$ (4) & 4.6 (6) \\
\hline $\mathrm{C}(2 \mathrm{M})$ & $0.855 \quad(1)$ & -0.291 & $0.0938 \quad(5)$ & $7.0 \quad(8)$ \\
\hline $\mathrm{C}(3 \mathrm{M})$ & $0.678 \quad(2)$ & -0.261 & $0.0247 \quad$ (4) & 6.1 (8) \\
\hline $\mathrm{C}(4 \mathrm{M})$ & 0.402 (1) & -0.021 & 0.0160 & $4.6 \quad(6)$ \\
\hline $\mathrm{C}(5 \mathrm{M})$ & $0.518 \quad$ (1) & -0.433 & 0.1061 & $4.9 \quad(6)$ \\
\hline $\mathrm{C}(6 \mathrm{M})$ & $0.403 \quad(2)$ & -0.511 & 0.2074 & 9. (1) \\
\hline$C(7 M)$ & $0.042 \quad(2)$ & -0.265 & 0.2276 & (1) \\
\hline $\mathrm{C}(8 \mathrm{M})$ & $0.272 \quad(2)$ & 0.167 & 0.2198 & (1) \\
\hline $\mathrm{C}(9 \mathrm{M})$ & $0.750 \quad(2)$ & $0.128 \quad(2)$ & 0.1843 (4) & 8. (1) \\
\hline$C(1 \mathrm{~T})$ & 0.717 (1) & 0.273 (1) & 0.0351 & 3.5 (5) \\
\hline $\mathrm{C}(2 \mathrm{~T})$ & 0.583 (1) & 0.296 (1) & 0.0173 & 4.1 (5) \\
\hline$C(3 \mathrm{~T})$ & 0.752 (1) & 0.374 (1) & 0.0554 & 4.3 (6) \\
\hline $\mathrm{C}(4 \mathrm{~T})$ & $0.869 \quad(1)$ & $0.346 \quad(1)$ & 0.0783 & $3.5 \quad(5)$ \\
\hline$C(5 \mathrm{~T})$ & 0.843 (1) & $0.345 \quad$ (1) & 0.1096 & 4.0 (5) \\
\hline $\mathrm{C}(6 \mathrm{~T})$ & 0.943 (1) & 0.318 (1) & $0.1310 \quad(3)$ & $4.2 \quad(6)$ \\
\hline$C(7 T)$ & 1.071 (1) & $0.287 \quad$ (1) & 0.1200 & 4.2 (5) \\
\hline $\mathrm{C}(8 \mathrm{~T})$ & 1.096 (1) & 0.284 (1) & 0.0891 & $4.0 \quad(5)$ \\
\hline $\mathrm{C}(9 \mathrm{~T})$ & 0.997 (1) & $0.316 \quad$ (1) & 0.0675 & 3.8 (5) \\
\hline
\end{tabular}

a) $\quad B_{\text {iso }}=\frac{4}{3}\left(a^{2} B_{11}+b^{2} B_{22}+c^{2} B_{33}\right)$.

esters $(\mathbf{2} \mathbf{a}-\mathbf{g})$ in $90-97 \%$ yield (Chart 1$)$. The infrared (IR) spectra of $\mathbf{2 a}-\mathbf{g}$ showed the amido and ester carbonyl absorptions at $1640-1660 \mathrm{~cm}^{-1}$ and $1730-1750 \mathrm{~cm}^{-1}$, respectively. In the proton nuclear magnetic resonance $\left({ }^{1} \mathrm{H}-\mathrm{NMR}\right)$ spectra, a new signal 
TABLE II. Interatomic Distances

\begin{tabular}{ccc}
\hline \hline & \multicolumn{2}{c}{ Distances $(\AA)$} \\
\cline { 2 - 3 } Atoms & $\mathbf{4}$ & $\mathbf{5}^{6)}$ \\
\hline Hydrogen bonds $(\mathrm{O}-\mathrm{O})$ & & \\
$\mathrm{O}(3)-\mathrm{HO}(11)$ & $2.83(2)$ & - \\
$\mathrm{O}(1)-\mathrm{HO}(11)$ & - & 2.757 \\
$\mathrm{O}(10)-\mathrm{HO}(2)$ & - & 2.732 \\
Coordinate bondings & $2.41(2)$ & 2.349 \\
$\mathrm{Na}-\mathrm{O}(4)$ & $2.31(2)$ & 2.366 \\
$\mathrm{Na}-\mathrm{O}(6)$ & $2.52(2)$ & 2.503 \\
$\mathrm{Na}-\mathrm{O}(7)$ & $2.43(2)$ & 2.471 \\
$\mathrm{Na}-\mathrm{O}(8)$ & $2.52(2)$ & - \\
$\mathrm{Na}-\mathrm{O}(9)$ & $2.66(2)$ & \\
$\mathrm{Na}-\mathrm{O}(10)$ & $2.56(2)$ & \\
$\mathrm{Na}-\mathrm{O}(11)$ & $3.25(2)$ & \\
Contacts around $\mathrm{Br}(\mathrm{Br}-\mathrm{O}$ or $\mathrm{N})$ & $3.41(2)$ & \\
$\mathrm{Br}-\mathrm{HO}(3 \mathrm{~T})$ & $3.18(2)$ & \\
$\mathrm{Br}-\mathrm{HO}(4)^{a)}$ & $3.54(2)$ & \\
$\mathrm{Br}-\mathrm{HO}(10)^{a)}$ & & \\
$\mathrm{Br}-\mathrm{HN}(1 \mathrm{~T})^{a)}$ & & \\
\hline
\end{tabular}

a) Atoms of an adjacent molecule translated at $1+x, y, z$.

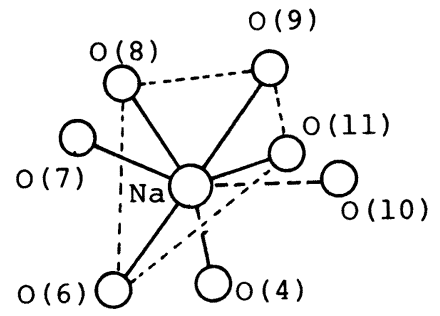

Fig. 6. Distorted Octahedral Coordination of $\mathrm{Na}^{+}$Ion in $4 \mathbf{e}$

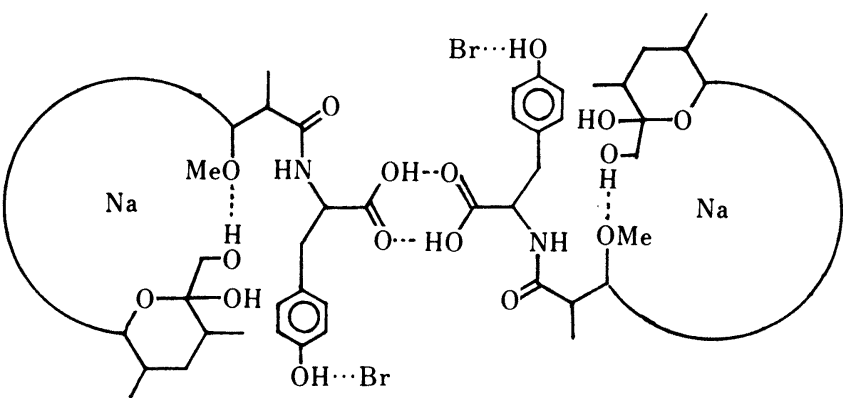

Fig. 7. Dimerization of Carboxyl Groups in $4 \mathbf{e}$

corresponding to the benzyl methylene protons appeared around $\delta 5.18 \mathrm{ppm}$ as a singlet.

Debenzylation of $\mathbf{2 a}-\mathbf{g}$ over $5 \%$ palladium on charcoal $(\mathrm{Pd}-\mathrm{C})$ under a hydrogen atmosphere proceeded in $83-99 \%$ yield to give monensylamino acids $(3 \mathbf{a}-\mathbf{g})$. The structures of $3 \mathbf{a}-\mathbf{g}$ were confirmed by their ${ }^{1} \mathrm{H}-\mathrm{NMR}$ spectra, in which the methylene signals of benzyl groups disappeared completely.

Sodium bromide complexes $(\mathbf{4 a}-\mathbf{g})$ of $3 \mathbf{a}-\mathbf{g}$, prepared according to the procedure reported previously, ${ }^{6}$ were recrystallized from appropriate solvents. The elemental and fast atom bombardment mass spectral (FAB-MS) analysis of the complexes were consistent with 
TABLE III.

\begin{tabular}{|c|c|c|}
\hline \multirow{2}{*}{ Atoms } & \multicolumn{2}{|c|}{ Angles $\left({ }^{\circ}\right)$} \\
\hline & $4 e$ & $5^{6)}$ \\
\hline \multicolumn{3}{|l|}{ Interatomic angles } \\
\hline $\mathrm{O}(4)-\mathrm{Na}-\mathrm{O}(6)$ & $77.9(3)$ & $74.1(3)$ \\
\hline $\mathrm{O}(4)-\mathrm{Na}-\mathrm{O}(7)$ & $137.4(4)$ & $137.8(4)$ \\
\hline $\mathrm{O}(4)-\mathrm{Na}-\mathrm{O}(8)$ & $105.1(3)$ & $110.3(3)$ \\
\hline $\mathrm{O}(4)-\mathrm{Na}-\mathrm{O}(9)$ & $109.3(3)$ & $102.2(3)$ \\
\hline $\mathrm{O}(4)-\mathrm{Na}-\mathrm{O}(10)$ & $73.9(3)$ & - \\
\hline $\mathrm{O}(4)-\mathrm{Na}-\mathrm{O}(11)$ & $124.0(3)$ & $114.4(3)$ \\
\hline $\mathrm{O}(6)-\mathrm{Na}-\mathrm{O}(7)$ & $68.7(3)$ & $69.0(2)$ \\
\hline $\mathrm{O}(6)-\mathrm{Na}-\mathrm{O}(8)$ & $115.3(4)$ & $114.8(3)$ \\
\hline $\mathrm{O}(6)-\mathrm{Na}-\mathrm{O}(9)$ & $172.7(3)$ & $175.9(3)$ \\
\hline $\mathrm{O}(6)-\mathrm{Na}-\mathrm{O}(10)$ & $130.9(3)$ & - \\
\hline $\mathrm{O}(6)-\mathrm{Na}-\mathrm{O}(11)$ & $108.5(4)$ & $116.2(3)$ \\
\hline $\mathrm{O}(7)-\mathrm{Na}-\mathrm{O}(8)$ & $68.5(3)$ & $69.5(2)$ \\
\hline $\mathrm{O}(7)-\mathrm{Na}-\mathrm{O}(9)$ & $105.4(3)$ & $113.9(3)$ \\
\hline $\mathrm{O}(7)-\mathrm{Na}-\mathrm{O}(10)$ & $148.7(3)$ & - \\
\hline $\mathrm{O}(7)-\mathrm{Na}-\mathrm{O}(11)$ & $92.1(3)$ & $100.0(3)$ \\
\hline $\mathrm{O}(8)-\mathrm{Na}-\mathrm{O}(9)$ & $64.8(3)$ & $64.7(2)$ \\
\hline $\mathrm{O}(8)-\mathrm{Na}-\mathrm{O}(10)$ & $110.5(3)$ & - \\
\hline $\mathrm{O}(8)-\mathrm{Na}-\mathrm{O}(11)$ & $119.3(4)$ & $118.8(3)$ \\
\hline $\mathrm{O}(9)-\mathrm{Na}-\mathrm{O}(10)$ & $52.4(3)$ & - \\
\hline $\mathrm{O}(9)-\mathrm{Na}-\mathrm{O}(11)$ & $66.8(3)$ & $66.7(3)$ \\
\hline $\mathrm{O}(10)-\mathrm{Na}-\mathrm{O}(11)$ & $60.2(3)$ & - \\
\hline \multicolumn{3}{|l|}{ Backbone torsion angles } \\
\hline$C(1)-C(2)-C(3)-C(4)$ & 61. (1) & 62.6 \\
\hline$C(2)-C(3)-C(4)-C(5)$ & 67. (1) & -83.0 \\
\hline $\mathrm{C}(3)-\mathrm{C}(4)-\mathrm{C}(5)-\mathrm{O}(5)$ & 133. (1) & -174.2 \\
\hline$C(4)-C(5)-O(5)-C(9)$ & -167. & -174.2 \\
\hline $\mathrm{C}(5)-\mathrm{O}(5)-\mathrm{C}(9)-\mathrm{O}(6)$ & $65.2(9)$ & 65.9 \\
\hline $\mathrm{O}(5)-\mathrm{C}(9)-\mathrm{O}(6)-\mathrm{C}(12)$ & 89. (1) & 88.8 \\
\hline$C(9)-O(6)-C(12)-C(13)$ & 130. (1) & 127.5 \\
\hline $\mathrm{O}(6)-\mathrm{C}(12)-\mathrm{C}(13)-\mathrm{O}(7)$ & 60. (1) & 60.4 \\
\hline$C(12)-C(13)-O(7)-C(16)$ & -164 & -167.9 \\
\hline$C(13)-O(7)-C(16)-C(17)$ & 156. (1) & 151.2 \\
\hline $\mathrm{O}(7)-\mathrm{C}(16)-\mathrm{C}(17)-\mathrm{O}(8)$ & $-69 .(1)$ & -69.6 \\
\hline $\mathrm{C}(16)-\mathrm{C}(17)-\mathrm{O}(8)-\mathrm{C}(20)$ & -169 & -166.6 \\
\hline$C(17)-O(8)-C(20)-C(21)$ & -112 & -112.1 \\
\hline $\mathrm{O}(8)-\mathrm{C}(20)-\mathrm{C}(21)-\mathrm{O}(9)$ & 50. (1) & 45.8 \\
\hline $\mathrm{C}(20)-\mathrm{C}(21)-\mathrm{O}(9)-\mathrm{C}(25)$ & -172 & 173.9 \\
\hline $\mathrm{C}(21)-\mathrm{O}(9)-\mathrm{C}(25)-\mathrm{C}(26)$ & 178. (1) & -174.8 \\
\hline $\mathrm{O}(9)-\mathrm{C}(25)-\mathrm{C}(26)-\mathrm{O}(11)$ & $-68 .(1)$ & -55.9 \\
\hline
\end{tabular}

the structures $4 \mathbf{a}-\mathbf{g}$.

\section{Results and Discussion}

The crystal structure of the $\mathrm{NaBr}$ complex of monensyltyrosine (4e) was established by single crystal analysis using the heavy atom method as described in Experimental. The stereodrawing and the numbering of the atoms are shown in Figs. 3 and 4, respectively. The chemical structure per asymmetric unit in the crystal structure consists of one $\mathrm{Br}^{-}$ion, one neutral molecule of $4 \mathbf{e}$ and one $\mathrm{Na}^{+}$ion. The $\mathrm{X}$-ray crystal analysis revealed that the molecule adopts a pseudocyclic conformation with the $\mathrm{O}(3)$ methoxy oxygen being hydrogen-bonded to the 
TABLE IV. Chemical Shifts of $-\mathrm{OCH}_{3}$ in Free Acids $(\mathbf{1}, \mathbf{3 a}-\mathbf{g})$

and $\mathrm{NaBr}$ Complexes $(5,4 \mathbf{a}-\mathbf{g})$

\begin{tabular}{clccc}
\hline \hline \multirow{2}{*}{ Compounds } & & \multicolumn{3}{c}{ Chemical shifts of $-\mathrm{OCH}_{3} \delta(\mathrm{ppm})\left(\mathrm{CDCl}_{3}\right)$} \\
\cline { 3 - 5 } & & Free acids & $\mathrm{NaBr}$ complexes & $\Delta \delta$ \\
\hline \multirow{2}{*}{ Monensin } & & 58.05 & 58.17 & +0.12 \\
a & $-\mathrm{H}$ & 58.37 & 62.24 & +3.87 \\
b & $-\mathrm{CH}_{3}$ & 58.48 & 62.61 & +4.13 \\
c & $-\mathrm{CH}_{2} \mathrm{OH}$ & 58.32 & 62.15 & +3.83 \\
d & $-\mathrm{CH}_{2} \mathrm{Ph}$ & 58.04 & 62.39 & +4.35 \\
e & $-\mathrm{CH}_{2} \mathrm{C}_{6} \mathrm{H}_{4} \mathrm{OH}$ & 58.01 & 60.72 & +2.71 \\
f & $-\mathrm{CH}_{2} \mathrm{CO}_{2} \mathrm{H}$ & 58.29 & 61.97 & +3.68 \\
g & $-\mathrm{CH}_{2} \mathrm{CH}_{2} \mathrm{CO}_{2} \mathrm{H}$ & 58.44 & 61.33 & +2.89 \\
\hline
\end{tabular}

$\mathrm{O}(11)$ hydroxy oxygen at the other end. This is the most characteristic and different feature as compared with the crystal structure of the $\mathrm{NaBr}$ complex of monensin (5), ${ }^{6}$ ) which possesses head-to-tail intramolecular hydrogen bonds as indicated in Fig. 5. The distances of hydrogen bonds of $\mathbf{4 e}$ and 5 are listed in Table II.

The $\mathrm{Na}^{+}$ion is coordinated to seven oxygen atoms with distorted octahedral coordination, despite the fact that the $\mathrm{Na}-\mathrm{O}(10)$ distance is longer than other $\mathrm{Na}-\mathrm{O}$ coordinate bondings (Table II, Fig. 6). The bromine atom, located between two neighboring molecules, is hydrogen-bonded to $\mathrm{OH}(3 \mathrm{~T}), \mathrm{OH}(4), \mathrm{OH}(10)$, and $\mathrm{NH}(1 \mathrm{~T})$ (Table II). The carboxyl group of tyrosine is not involved in a pseudocyclic conformation, but is dimerized with a carboxyl group of an adjacent molecule to contribute to a strong intermolecular contact, as illustrated in Fig. 7.

Although the coordination of the $\mathrm{Na}^{+}$ion of $4 \mathbf{e}$ is eventually almost the same as that of $\mathrm{NaBr}$ monensin (5), the $\mathrm{C}(3)-\mathrm{C}(4)$ and $\mathrm{C}(4)-\mathrm{C}(5)$ bonds of $4 \mathrm{e}$ are significantly rotated $\left(+160^{\circ}\right.$ and $-53^{\circ}$ ) compared with those of 5 , and consequently the chemically modified amino acid substituents occupy a position oriented toward the outside of a pseudocyclic molecule (Table III).

Spectral evidence for hydrogen bond formation between the $O(3)$ methoxy oxygen and the $\mathrm{O}(11)$ hydroxy proton was also obtained from the carbon-13 nuclear magnetic resonance $\left({ }^{13} \mathrm{C}-\mathrm{NMR}\right)$ spectra of $4 \mathbf{e}$ and free monensylamino acid (3e). The methoxy carbon of $4 \mathbf{e}$ resonated at $\delta 60.72 \mathrm{ppm}$ due to anisotropy of the hydrogen bond ${ }^{7)}$ while that of $3 \mathbf{e}$ appeared at $\delta 58.01 \mathrm{ppm}$ (Table IV). This downfield shift is in good agreement with the crystal structure obtained by X-ray analysis. Similar results have also been seen in the methoxy carbon signals of other $\mathrm{NaBr}$ complexes (4) which appeared $2.89-4.35 \mathrm{ppm}$ downfield relative to those of the corresponding monensylamino acids (3). Accordingly, the crystal structure of every $\mathrm{NaBr}$ complex seems to be virtually identical with that of $\mathbf{4 e}$.

Anticoccidial activities of $3 \mathbf{a}-\mathbf{g}$ were examined in vivo with Eimeria tennella-infected chicks. However, the test compounds, which seem to exist in vivo as sodium-complexed conformations quite similar to that of $4 \mathbf{e}^{6)}$ were inactive. Recently, Pospisil et al. isolated 3-Odemethylmonensin and found that the activity against Bacillus subtilis was less potent than that of the parent monensin. ${ }^{8}$ From this finding and results of our anticoccidial activity studies, it is likely that the presence of the polar $\mathrm{OH}$ group and the dissociable $\mathrm{COOH}$ function at the lipophilic region of monensin causes a remarkable decrease in the cationtransporting properties, and loss of ability to transport cations through biological membranes reduces the antibacterial properties. ${ }^{9)}$

In summary, the displacement of the carboxyl group by amino acids resulted in a 
conformational change of the complexed molecule, which involved the formation of a new intramolecular hydrogen bond between the $O(3)$ methoxy oxygen and the $O(11)$ hydroxy proton. Moreover, it is interesting to note that the antibacterial activities might be correlated with the presence of a non-hydrogen-bonded methoxy group on the lipophilic region of monensin. Further investigations on the correlation between chemical modifications and biological activities are in progress.

\section{Experimental}

All melting points were determined on a Yanagimoto micro melting point apparatus and are uncorrected. The FAB-MS were measured with a JEOL JMS DX-300 mass spectrometer, and the IR spectra with a JASCO IRA-2 spectrometer. The ${ }^{1} \mathrm{H}-\mathrm{NMR}$ spectra were recorded with JEOL JNM-MH-100 and JEOL GSX-400 spectrometers and the ${ }^{13} \mathrm{C}$-NMR spectra with a JEOL GSX-400 spectrometer in $\mathrm{CDCl}_{3}$ using tetramethylsilane as an internal standard. Singlet is abbreviated as s. Column chromatography was carried out on Silica gel BW-200 (Fuji Davison Chemicals, Ltd.). High-performance liquid chromatography (HPLC) was carried out on C.I.G. ODS- $\mathrm{C}_{18}-10 / 20(22 \mathrm{~mm}$ i.d. $\times 100 \mathrm{~mm}$, Kusano Kagakukikai Co.).

Monensylamino Acid Benzyl Esters (2a-g) A mixture of $1(200 \mathrm{mg}, 0.3 \mathrm{mmol})$ and $\mathrm{HOBt}(70 \mathrm{mg}, 0.36 \mathrm{mmol})$ was stirred at $5 \mathrm{C}$ for $30 \mathrm{~min}$ and then DCC $(85 \mathrm{mg}, 0.36 \mathrm{mmol})$ was added. After being stirred for $\mathrm{I} \mathrm{h}$, the reaction mixture was treated with a solution of amino acid benzyl ester $p$ - TsOH (or $\mathrm{HCl}$ ) salt $(0.4 \mathrm{mmol})$ and $N$ methylmorpholine $(0.06 \mathrm{ml}, 0.4 \mathrm{mmol})$ in tetrahydrofuran (THF) $(0.5 \mathrm{ml})$, and the stirring was continued at $5 \mathrm{C}$ for $12 \mathrm{~h}$. The mixture was evaporated to dryness below $5{ }^{\circ} \mathrm{C}$ to give a white powder, which was suspended in EtOAc $(30 \mathrm{ml})$ and filtered off. The EtOAc extract was washed with $10 \%$ citric acid solution, $4 \%{ }_{0} \mathrm{NaHCO}_{3}$ and water. successively, and evaporated to dryness. The residue was chromatographed on Silica gel $\left(\mathrm{CHCl}_{3}-\mathrm{MeOH}\right)$ to give a white amorphous powder. Spectral data of 2a-g are summarized in Table V. 2a. Monensinamidoacetic acid benzyl ester; 2b, 2-monensinamidopropanoic acid benzyl ester; $2 \mathbf{c}$, 3-hydroxy-2-monensinamidopropanoic acid benzyl ester; 2d, 2-monensinamido-3-phenylpropanoic acid benzyl ester; 2e, 3-(4-hydroxyphenyl)-2-monensinamidopropanoic acid benzyl ester; $\mathbf{2 f}$, monensinamidobutanedioic acid dibenzyl ester; $2 \mathbf{g}$, 2-monensinamidopentanedioic acid dibenzyl ester; monensinamido-, 2-[2-ethyloctahydro-3'-methyl-5'-[tetrahydro-6-hydroxy-6-(hydroxymethyl)-3,5-dimethyl-

TABle V. Spectral Data for Monensylamino Acid Benzyl Esters (2a-g)

\begin{tabular}{|c|c|c|c|c|c|c|c|}
\hline \multirow{2}{*}{2} & \multirow{2}{*}{$\begin{array}{l}\text { Condensed amino acid } \\
\text { benzyl esters }\end{array}$} & \multirow{2}{*}{$\mathrm{R}$} & \multirow{2}{*}{$\begin{array}{l}\text { Yield } \\
(\%)\end{array}$} & \multicolumn{2}{|c|}{ IR $v_{\max }^{\mathrm{KBr}} \mathrm{cm}^{-1}$} & \multicolumn{2}{|c|}{${ }^{1} \mathrm{H}-\mathrm{NMR}\left(\mathrm{CDCl}_{3}\right) \delta(\mathrm{ppm})$} \\
\hline & & & & $\mathrm{CONH}$ & COOBzl & $-\mathrm{OCH}_{3}, 3 \mathrm{H}, \mathrm{s}$ & $-\mathrm{OC}_{2} \mathrm{Ph}, 2 \mathrm{H}, \mathrm{s}$ \\
\hline $\mathbf{a}$ & GlyOBzl·TsOH & $-\mathrm{H}$ & 95 & 1655 & 1750 & 3.44 & 5.19 \\
\hline b & L-AlaOBzl $\cdot \mathrm{TsOH}$ & $-\mathrm{CH}_{3}$ & 90 & 1650 & 1740 & 3.38 & 5.16 \\
\hline c & L-SerOBzl $\cdot \mathrm{HCl}$ & $-\mathrm{CH}_{2} \mathrm{OH}$ & 95 & 1640 & 1745 & 3.37 & 5.19 \\
\hline d & $\mathrm{L}-\mathrm{PheOBzl} \cdot \mathrm{TsOH}$ & $-\mathrm{CH}_{2} \mathrm{Ph}$ & 97 & 1660 & 1740 & 3.16 & 5.18 \\
\hline $\mathbf{e}$ & L-TyrOBzl $\cdot \mathrm{TsOH}$ & $-\mathrm{CH}_{2} \mathrm{C}_{6} \mathrm{H}_{4} \mathrm{OH}$ & 95 & 1660 & 1740 & 3.28 & 5.18 \\
\hline f & $\mathrm{L}-\mathrm{Asp}(\mathrm{OBzl}) \mathrm{OBzl} \cdot \mathrm{TsOH}$ & $-\mathrm{CH}_{2} \mathrm{CO}_{2} \mathrm{Bzl}$ & 95 & 1660 & 1730 & 3.30 & $5.08,5.16$ \\
\hline $\mathbf{g}$ & L-Glu(OBzl)OBzl $\cdot \mathrm{TsOH}$ & $-\mathrm{CH}_{2} \mathrm{CH}_{2} \mathrm{CO}_{2} \mathrm{Bzl}$ & 90 & 1660 & 1730 & 3.33 & $5.08,5.13$ \\
\hline
\end{tabular}

TABLE VI. Spectral Data for Monensylamino Acids $(3 \mathbf{a}-\mathbf{g})$

\begin{tabular}{|c|c|c|c|c|c|c|c|}
\hline \multirow{2}{*}{3} & \multirow{2}{*}{$\mathbf{R}$} & \multirow{2}{*}{$\begin{array}{c}\text { Reaction } \\
\text { time } \\
\text { (min) }\end{array}$} & \multicolumn{2}{|c|}{ Yield $(\%)$} & \multirow{2}{*}{$\begin{array}{c}{[\alpha]_{\mathrm{D}}^{24}} \\
\text { in } \mathrm{EtOH} \\
(c)\end{array}$} & \multicolumn{2}{|c|}{ IR $v_{\max }^{\mathrm{KBr}} \mathrm{cm}^{-1}$} \\
\hline & & & $2 \rightarrow 3$ & Total (from 1) & & $\mathrm{CONH}$ & $\mathrm{COOH}$ \\
\hline $\mathbf{a}$ & $-\mathrm{H}$ & 20 & 95 & 90 & $46(0.25)$ & 1655 & 1730 \\
\hline b & $-\mathrm{CH}_{3}$ & 20 & 99 & 89 & $41(0.51)$ & 1650 & 1730 \\
\hline c & $-\mathrm{CH}_{2} \mathrm{OH}$ & 15 & 94 & 90 & $49(0.26)$ & 1650 & 1730 \\
\hline d & $-\mathrm{CH}_{2} \mathrm{Ph}$ & 20 & 88 & 85 & $53(0.25)$ & 1650 & 1730 \\
\hline e & $-\mathrm{CH}_{2} \mathrm{C}_{6} \mathrm{H}_{4} \mathrm{OH}$ & 40 & 83 & 79 & $61(0.25)$ & 1640 & 1730 \\
\hline f & $-\mathrm{CH}_{2} \mathrm{CO}_{2} \mathrm{H}$ & 25 & 92 & 83 & $25(0.50)$ & 1640 & 1720 \\
\hline $\mathbf{g}$ & $-\mathrm{CH}_{2} \mathrm{CH}_{2} \mathrm{CO}_{2} \mathrm{H}$ & 20 & 94 & 87 & $40(0.26)$ & 1640 & 1720 \\
\hline
\end{tabular}


TABLE VII. Physicochemical Data for $\mathrm{NaBr}$ Complexes $(\mathbf{4 a -}-\mathbf{g})$

\begin{tabular}{|c|c|c|c|c|c|c|c|}
\hline \multirow{2}{*}{4} & \multirow{2}{*}{$\mathrm{R}$} & \multirow{2}{*}{$\begin{array}{c}\left.\mathrm{mp}(\mathrm{C})^{a}\right) \\
\text { (Recryst. solvent) }\end{array}$} & \multirow{2}{*}{$\begin{array}{c}\text { FAB-MS } \\
m / z\end{array}$} & \multirow{2}{*}{ Formula } & \multicolumn{3}{|c|}{$\begin{array}{l}\text { Analysis (\%) } \\
\text { Found (Calcd) }\end{array}$} \\
\hline & & & & & $\mathrm{C}$ & $\mathrm{H}$ & $\mathrm{N}$ \\
\hline $\mathbf{a}$ & $-\mathrm{H}$ & $\begin{array}{c}154.5-155.5 \\
\left(\mathrm{MeOH}-\mathrm{Et}_{2} \mathrm{O}\right)\end{array}$ & $\begin{array}{c}750 \\
\left(\mathrm{M}^{+}-\mathrm{Br}\right)\end{array}$ & $\mathrm{C}_{38} \mathrm{H}_{65} \mathrm{NO}_{12} \mathrm{NaBr} \cdot 2 \mathrm{H}_{2} \mathrm{O}$ & $\begin{array}{r}52.91 \\
(52.65\end{array}$ & $\begin{array}{l}8.26 \\
8.02\end{array}$ & $\begin{array}{l}1.50 \\
1.61)\end{array}$ \\
\hline b & $-\mathrm{CH}_{3}$ & $\begin{array}{c}160-162 \\
\left(\mathrm{MeOH}-\mathrm{Et}_{2} \mathrm{O}\right)\end{array}$ & $\begin{array}{c}764 \\
\left(\mathrm{M}^{+}-\mathrm{Br}\right)\end{array}$ & $\mathrm{C}_{39} \mathrm{H}_{67} \mathrm{NO}_{12} \mathrm{NaBr} \cdot 2 \mathrm{H}_{2} \mathrm{O}$ & $\begin{array}{r}53.35 \\
(53.18\end{array}$ & $\begin{array}{l}8.31 \\
8.12\end{array}$ & $\begin{array}{l}1.66 \\
1.59)\end{array}$ \\
\hline c & $-\mathrm{CH}_{2} \mathrm{OH}$ & $\begin{array}{c}177-178 \\
\left(\mathrm{MeOH}-\mathrm{Et}_{2} \mathrm{O}\right)\end{array}$ & $\begin{array}{c}780 \\
\left(\mathrm{M}^{+}-\mathrm{Br}\right)\end{array}$ & $\mathrm{C}_{39} \mathrm{H}_{67} \mathrm{NO}_{13} \mathrm{NaBr}$ & $\begin{array}{r}54.43 \\
(54.41\end{array}$ & $\begin{array}{l}8.11 \\
7.84\end{array}$ & $\begin{array}{l}1.62 \\
1.63)\end{array}$ \\
\hline d & $-\mathrm{CH}_{2} \mathrm{Ph}$ & $\begin{array}{c}154-155.5 \\
\left(\mathrm{Et}_{2} \mathrm{O}-\text {-hexane }\right)\end{array}$ & $\begin{array}{c}841 \\
\left(\mathrm{M}^{+}-\mathrm{Br}+1\right)\end{array}$ & $\mathrm{C}_{45} \mathrm{H}_{71} \mathrm{NO}_{12} \mathrm{NaBr}$ & $\begin{array}{r}58.69 \\
(58.38\end{array}$ & $\begin{array}{l}7.77 \\
7.51\end{array}$ & $\begin{array}{l}1.52 \\
1.55)\end{array}$ \\
\hline $\mathbf{e}$ & $-\mathrm{CH}_{2} \mathrm{C}_{6} \mathrm{H}_{4} \mathrm{OH}$ & $\begin{array}{c}201.3-201.9 \\
\left(\mathrm{MeOH}-\mathrm{Et}_{2} \mathrm{O}\right)\end{array}$ & $\begin{array}{c}857 \\
\left(M^{+}-\mathrm{Br}+1\right)\end{array}$ & $\mathrm{C}_{45} \mathrm{H}_{71} \mathrm{NO}_{13} \mathrm{NaBr}$ & $\begin{array}{r}57.34 \\
(57.69\end{array}$ & $\begin{array}{l}7.54 \\
7.64\end{array}$ & $\begin{array}{l}1.28 \\
1.49)\end{array}$ \\
\hline f & $-\mathrm{CH}_{2} \mathrm{CO}_{2} \mathrm{H}$ & $\begin{array}{c}153-155 \\
\left(\mathrm{Et}_{2} \mathrm{O}-\text {-hexane }\right)\end{array}$ & $\begin{array}{c}808 \\
\left(\mathrm{M}^{+}-\mathrm{Br}\right)\end{array}$ & $\mathrm{C}_{40} \mathrm{H}_{67} \mathrm{NO}_{14} \mathrm{NaBr}$ & $\begin{array}{r}54.42 \\
(54.05\end{array}$ & $\begin{array}{l}7.44 \\
7.60\end{array}$ & $\begin{array}{l}1.53 \\
1.58)\end{array}$ \\
\hline $\mathbf{g}$ & $-\mathrm{CH}_{2} \mathrm{CH}_{2} \mathrm{CO}_{2} \mathrm{H}$ & $\begin{array}{c}170-173 \\
\left(\mathrm{Et}_{2} \mathrm{O}-\text {-hexane }\right)\end{array}$ & $\left(\mathrm{M}^{+}-\mathrm{Br}\right)$ & $\mathrm{C}_{41} \mathrm{H}_{69} \mathrm{NO}_{14} \mathrm{NaBr}$ & $\begin{array}{r}54.39 \\
(54.54\end{array}$ & $\begin{array}{l}7.70 \\
7.70\end{array}$ & $\begin{array}{l}1.60 \\
1.55)\end{array}$ \\
\hline
\end{tabular}

a) Colorless prisms.

$2 H$-pyran-2-yl][2,2'-bifuran]-5-yl]-9-hydroxy- $\beta$-methoxy- $\alpha, \gamma, 2,8$-tetramethyl-1,6-dioxaspiro[4,5]-decane-7-butaneamido-.

Monensylamino Acids $(3 \mathbf{a}-\mathbf{g})$ - A solution of $2 \mathbf{a}-\mathbf{g}(100 \mathrm{mg})$ in $\mathrm{EtOH}(3 \mathrm{ml})$ was hydrogenated in the presence of $5 \% \mathrm{Pd}-\mathrm{C}(10 \mathrm{mg})$ at atmospheric pressure of hydrogen for $15-40 \mathrm{~min}$. The catalyst was filtered off, and the filtrate was evaporated to dryness. The residue was purified by column chromatography on silica gel $\left(\mathrm{CHCl}_{3-}\right.$ $\mathrm{MeOH})$ followed by HPLC to give an amorphous powder. Spectral data are summarized in Table VI. 3a, Monensinamidoacetic acid; 3b, 2-monensinamidopropanoic acid; 3c, 3-hydroxy-2-monensinamidopropanoic acid; 3d, 2-monensinamido-3-phenylpropanoic acid; 3e, 3-(4-hydroxyphenyl)-2-monensinamidopropanoic acid; 3f, monensinamidobutanedioic acid: 3g. 2-monensinamidopentanedioic acid.

$\mathrm{NaBr}$ Complexes of Monensylamino Acids (4a-g)-A solution of $3 \mathbf{a}-\mathbf{g}(100 \mathrm{mg})$ in $\mathrm{CHCl}_{3}(5 \mathrm{ml})$ was treated with an equivalent amount of $\mathrm{NaBr}$ in $\mathrm{MeOH}(5 \mathrm{ml})$. The mixture was evaporated to dryness to give an amorphous powder. Recrystallization of $\mathbf{4 a -}-\mathbf{g}$ from $\mathrm{MeOH}-\mathrm{Et}_{2} \mathrm{O}$ or $\mathrm{Et}_{2} \mathrm{O}$-hexane gave colorless prisms. Physicochemical, analytical and FAB-MS data are summarized in Table VII.

X-Ray Analysis-Transparent crystals were obtained from $\mathrm{MeOH}-\mathrm{Et}_{2} \mathrm{O}$ solution. Oscillation and Weissenberg photographs indicated the crystal to be orthorhombic with space group $P 2_{1} 2_{1} 2_{1}$ (absent reflection: $h=$ $2 n+1$ for $(h 00), k=2 n+1$ for $(0 k 0), l=2 n+1$ for $(00 l))$. Unit cell dimensions and diffraction intensities were measured with graphite-monochromated $\mathrm{Cu} K_{\alpha}$ radiation $(\lambda=1.5405 \AA)$ on a Rigaku AFC-5 computer-controlled diffractometer. Crystal data and parameters for data collection are summarized in Table VIII. The unit cell parameters were determined by a least-squares fit of $2 \theta$ angles for 20 reflections $\left(30^{\circ} \leqq 2 \theta \leqq 60^{\circ}\right)$. The $\omega-2 \theta$ scan technique was employed for the intensity recording. The peak counts were corrected with background counts for $5 \mathrm{~s}$ at both ends of the scan range. Four standard reflections were measured at every 100 reflection intervals and showed no significant deterioration throughout the data collection. The observed intensities were corrected for Lorentz and polarization effects. Correction of the absorption effect was also done by using an empirical method based on the $\phi$ scan at $\chi=90$.

The structure was solved by the heavy atom method and successive Fourier syntheses. The obtained positional parameters were then refined by a full-matrix least-squares analysis with isotropic temperature factors and then by a block-diagonal least-squares analysis with anisotropic ones. The positions of the geometrically reasonable hydrogen atoms were determined on a difference Fourier map and included in subsequent refinements with isotropic temperature factors.

The function minimized was $\sum(1)\left(\left|F_{\mathrm{O}}\right|-\left|F_{\mathrm{C}}\right|\right)^{2}$, where $\left|F_{\mathrm{O}}\right|$ and $\left|F_{\mathrm{C}}\right|$ are the observed and calculated structure amplitudes, respectively. The weighting scheme used for refinement is as follows: $\omega=1.0 /\left[\sigma\left(F_{\mathrm{O}}\right)^{2}+a\left|F_{\mathrm{O}}\right|+b\left|F_{\mathrm{O}}\right|^{2}\right]$ for $\left(F_{\mathrm{O}}\right)^{2}>3 \sigma\left(F_{\mathrm{O}}\right)^{2}$, where $\left(F_{\mathrm{O}}\right)^{2}$ is the standard deviation of the intensity based on counting statistics. In the final refinements, the coefficients used were 0.0894 and 0.0034 for $a$ and $b$, respectively. The discrepancy indices $R_{\mathrm{F}}\left(=\Sigma\left\|F_{\mathrm{O}}|-| F_{\mathrm{C}}\right\| / \Sigma\left|F_{\mathrm{O}}\right|\right)$ and $R_{\mathrm{wF}}\left(=\left[\Sigma(\omega)\left(\left|F_{\mathrm{O}}\right|-\left|F_{\mathrm{C}}\right|\right)^{2} /\left(\omega F_{\mathrm{O}}^{2}\right]^{1 / 2}\right)\right.$ were 0.083 and 0.092 for 3781 observed reflections, respectively, and $S\left(=\left[\Sigma(1)\left(\left|F_{\mathrm{O}}\right|-\left|F_{\mathrm{C}}\right|\right)^{2} /(M-N)\right]^{1 / 2}\right.$, where $M=$ number of observations and $N=$ number of vari- 
TABLE VIII. Summary of Crystal Data and Data Collection

\begin{tabular}{ll}
\hline \hline Formula & $\mathrm{C}_{45} \mathrm{H}_{71} \mathrm{NO}_{13} \cdot \mathrm{NaBr}$ \\
$M_{\mathrm{r}}$ & 936.954 \\
Space group & $P 2_{1} 2_{1} 2_{1}$ \\
$a(\AA)$ & $9.919(4)$ \\
$b(\AA)$ & $11.793(4)$ \\
$c(\AA)$ & $43.033(18)$ \\
$V\left(\AA^{3}\right)$ & $5034(6)$ \\
$Z$ & 4 \\
$D_{\mathrm{c}}\left(\mathrm{g} \cdot \mathrm{cm}^{-3}\right)$ & 1.236 \\
Absorption coefficient $\left(\mathrm{cm}^{-1}\right)$ & 16.64 \\
$F(0,0,0)$ & 1992 \\
Crystal size (mm $\left.{ }^{-3}\right)$ & $0.3 \times 0.4 \times 0.2$ \\
$T$ of data collection $\left({ }^{\circ} \mathrm{C}\right)$ & 20 \\
Data collection method & $\omega-2 \theta \mathrm{scan}$ \\
Scan speed in $2 \theta\left(\right.$ deg $\left.\min ^{-1}\right)$ & 4 \\
Scan range in $\omega(\operatorname{deg})$ & $1.75+0.15 \tan \theta$ \\
Data range measured $(\mathrm{deg})$ & $2<2 \theta<130$ \\
No. of unique data measured & 4838 \\
No. of data with $F_{\mathrm{O}} \geqq 3 \sigma\left(F_{\mathrm{O}}\right)$ & 3781 \\
No. of variables & 835 \\
$R_{\mathrm{F}}\left(R_{\mathrm{wF}}\right)$ & $0.083(0.092)$ \\
\hline
\end{tabular}

ables) was 1.17. None of the positional parameters shifted more than one-third of their standard deviations. For all crystallographic computations, the UNICS programs ${ }^{10)}$ were used, and atomic scattering factors and the terms of the anomalous dispersion correction were those given by the International Tables for X-Ray Crystallography. ${ }^{11}$ The calculations were performed on a Micro Vax II computer at the Computation Center of Osaka University of Pharmaceutical Sciences. ${ }^{12}$

Acknowledgment We are grateful to Miss. S. Kato, Miss T. Matsui and Miss T. Naito of the Laboratory of Instrumental Analysis of our university for NMR spectral measurements and elemental analyses. This work was supported in part by a Grant-in-Aid for Scientific Research from the Ministry of Education, Science and Culture of Japan.

\section{References}

1) a) E. N. Duesler and I. C. Paul, "Polyether Antibiotics: Naturally Occurring Acid Ionophores," Vol. 2, ed. by J. W. Westley, Marcel Dekker, New York, 1982; b) W. L. Duax, G. D. Smith, and P. D. Strong, J. Am. Chem. Soc., 102, 6725 (1980); c) W. Pangborn, W. L. Duax, and D. Langs, ibid., 109, 2163 (1987).

2) W. P. Reed, "Polyether Antibiotics: Naturally Occurring Acid Ionophores," Vol. 1, ed. by J. W. Westley, Marcel Dekker, New York, 1982.

3) a) B. G. Cox, N. V. Truong, J. Rzeszotarsta, and H. Schneider, J. Am. Chem. Soc., 106, 5965 (1984); b) H. Tsukube, K. Takagi, T. Higashiyama, T. Iwachido, and N. Hayama, J. Chem. Soc., Chem. Commun., 1986, 448.

4) a) J. W. Westley, R. H. Evans, Jr., L. H. Sello, N. Troupe, C. Liu, and P. A. Miller, J. Antibiot., 34, 1248 (1981); b) J. W. Westley, C. Liu, R. H. Evans, Jr., L. H. Sello, N. Troupe, and T. Hermann, J. Antibiot., 36, 1195 (1983).

5) B. G. Cox, P. Firman, and H. Schneider, J. Am. Chem. Soc., 107, 4297 (1985).

6) D. L. Ward, K. T. Wei, J. C. Hoogerheid, and A. I. Popov, Acta Crystallogr., Sect. B, B34, 110 (1978).

7) I. I. Schuster, J. Org. Chem., 46, 5110 (1981).

8) S. Pospisil, P. Sedmera, J. Vokoun, and Z. Vanck, J. Antibiot., 40, 555 (1987).

9) A. Cuer and G. Dauphin, Tetrahedron, 41, 3725 (1985).

10) The Universal Crystallographic Computing System-Osaka; The Computation Center, Osaka University, Osaka, 1979.

11) “International Tables for X-Ray Crystallography,” Vol. 4, Kynoch, Birmingham, 1974.

12) Tables of observed and calculated structure factors, anisotropic thermal parameters of nonhydrogen atoms and atomic coordinates of hydrogen atoms, and a stereoscopic view of the crystal packing are available from one of the authors (A.N.) on request. 